The University of Southern Mississippi The Aquila Digital Community

Faculty Publications

$8-1-2003$

\title{
Prey Nutritional Quality Interacts With Chemical Defenses to Affect Consumer Feeding and Fitness
}

Edwin Cruz-Rivera

University of Southern Mississippi

Mark E. Hay

University of Southern Mississippi

Follow this and additional works at: http://aquila.usm.edu/fac_pubs

Part of the Marine Biology Commons

\section{Recommended Citation}

Cruz-Rivera, E., Hay, M. E. (2003). Prey Nutritional Quality Interacts With Chemical Defenses to Affect Consumer Feeding and Fitness. Ecological Monographs, 73(3), 483-506.

Available at: http://aquila.usm.edu/fac_pubs/3225 
ents in Gosport, Indiana. Reiterating her devotion to texts in context, Dégh criticizes "naive" folklorists (citing Brunvand and Sanderson) who believe "that we can assemble variants of media legend-texts for a Finnish School-type comparative study... to establish historical continuity and trace the origins of legends" ( $p$. 309). Actually, Richard M. Dorson was the only folklorist I know of who claimed to use the Finnish Method on modern legends; in fact, both Sanderson and I criticized his method and conclusions about "The Death Car," which utilized that method. Although comparative approaches are still very much part of the basic toolbox of the folklorist, few use these methods today to seek origins.

In Chapter 5, "The Landscape and the Climate of the Legend," Dégh focuses on beliefs, quoting lengthy written personal accounts of "haunted houses." Dégh questions whether such descriptions truly are folk legends but "tentatively" assigns them the label "autobiographical haunting legends" (p. 362), a category some folklorists would reject as genuine folklore. While noting that the Motif-Index validates many details as folkloric, Dégh lists no motif numbers, suggesting, rather, that "interested readers should let their fingers do the walking" (p. 378). Surprisingly, after criticizing folklorists for presenting summaries rather than actual transcribed texts, Dégh herself uses three dozen "brief excerpts" instead of "fully contextualized performances" to present another major example, legends of typical haunted sites (pp. 389-92).

The last chapter of Dégh's book, "Texts, Contexualized and Processed," takes Dégh's definition of legend about as far as it can go by characterizing legend as "a traditional or nontraditional story ... communicated by someone to someone else in some way" and even suggesting that "the legend can exist before it has been put into words" (p. 401). Dégh insists that we must recognize the existence of not just legendary narratives, fragments, or related beliefs, but even of "postulated legends" (p. 402; original emphasis), such as "a reference that calls to mind a whole legend" (p. 405).

Finally, Dégh discusses "Criminal Ostension," referring to product-tampering cases in the 1980s and school assaults of later years, which, she points out, "concern imitation and repetition" and thus "follow the model of folklore" (pp. 438-39). This view of legends in the making is confirmed by the lore surrounding the terrorist attacks and anthrax scares beginning the very year that Legend and Belief was published. Dégh is well aware of the hazards of studying living contemporary legends and warns that "whatever folklorists can conclude today will be invalidated by events of tomorrow" (p. 201). This calls to mind many recent studies by folklorists Gillian Bennett, Jan Brunvand, Bill Ellis, Gary Fine and Pat Turner, and Ellissa Henken and by nonfolklorists Susan Blackmore and Robert Fulford, all of whom make similar suggestions in different ways.

Even with the current explosion of legend studies and her own Herculean efforts, Dégh asserts that we do not have "straight answers on a silver platter" but instead only questions, for which "the answers, because of the nature of things, must be left open indefinitely" (p. 428). To disagree, I, for one, believe that we can agree on some basic matters of legend definition and interpretation as long as folklorists are willing to make judicial assessments of narrative structure, belief, performance, tradition, and motif patterns. After all, eventually all lawsuits are settled, even if it takes a Supreme Court appeal and DNA evidence to reach agreement.

\section{Casa Mañana: The Morrow Collection of} Mexican Popular Arts. Ed. Susan Danly. (Albuquerque: University of New Mexico Press, for the Mead Art Museum, Amherst College, 2002. Pp. xiv +199 , photographs, notes, appendix, bibliography, index.)

\section{Chris Goertzen \\ University of Southern Mississippi}

This series of essays concerns Dwight and Elizabeth Cutter Morrow and their collecting of Mexican artifacts while the former was ambassador to Mexico during 1927-30. The Morrows furnished their weekend house in Cuernavaca (then two hours from Mexico City) with crafts bought in Mexico City and during their travels. 
The house, which they named Casa Mañana, became "an informal setting for important discussions with Mexico's leading political and cultural figures" (p. xi) and the craft objects a collective manifestation of the Morrows' informed affection for Mexico. The book's title is imprecise, because little of this volume concerns the Morrows' craft collection as a set of things. The focus is instead on the collecting process as an expression of U. S.-Mexican diplomacy and on how the visual arts came to play a critical role in defining Mexican cultural identity. The book came into being in association with an exhibit of this collection, now largely in the hands of Amherst College, Morrow's alma mater. Each essay appears in both English and Spanish. The translations are excellent; their inclusion makes the book seem meatier than it is.

In the first (and best) essay, "For Business or Pleasure: Exhibiting Mexican Folk Art, 1820 1930 ," James Oles analyzes the histories, contents, and contrasting tacit purposes of the first half-dozen exhibits of Mexican crafts (most outside of Mexico). These shows illustrated the interaction of upper-class Mexican and foreign romantic images of Mexico. This ideologically complex nation-building came to be symbolized by crafts made by Indians who were, then as now, "gloriously praised, yet economically and politically disenfranchised" (p. 27). Much the same ground is covered by Rick A. Lopez in the second essay, "The Morrows in Mexico: Nationalist Politics, Foreign Patronage, and the Promotion of Mexican Popular Arts," but with these themes now explored through biography and history. Susan Danly's "Casa Mañana" is the only essay to concentrate on Elizabeth Morrow's thoughts and actions. Morrow understood that ordinary citizens of the United States were more likely to learn about life in Mexico through exposure to Mexico's fine and vernacular arts than through political speeches or prose. Danly's discussion of the artifacts concentrates on their social meanings. For instance, two wooden trays-one with upper-class people depicted on it and the other featuring illustrations of members of the lower class- "echo the fascination with racial distinctions found in Mexican caste paintings produced in the seventeenth and eighteenth centuries" ( $\mathrm{p}$. 105).

The last essay connects with the others only through Dwight Morrow's biography. In "Painting of a Spark of Hope: Diego Rivera's History of Cuernavaca and Morelos," Anthony W. Lee discusses Morrow's doubtless uneasy relationship with Rivera and the artistic nature and biographical and political significance of this mural, which Morrow commissioned from Rivera as a parting gift to his adopted Mexican city and state. Rivera, fresh from having been thrown out of an increasingly rigid Communist party, tried in this mural "to preserve the possibility of a dissenting tradition for some future moment, when those on the left could join together again" (p. 144). This essay convincingly plumbs Rivera's probable thinking about the mural, sketches the historical situation well, and constitutes the best writing on this mural as a work of art.

The book ends with a checklist of the 155 Mexican objects given to Amherst's Mead Art Museum in 1955. For each object, the catalog includes accession number, maker of the object if known, place of production (perhaps city and certainly state), date (within a few decades, if possible-not so helpful), medium, and measurements. Just over half of the entries include tiny black-and-white pictures of the objects. The citations of medium are too short; a few more words or slightly larger photographs could have clarified matters. Luckily, a fair number of the craft objects are represented in sizeable color photographs elsewhere.

This book adds little to our understanding of Mexican crafts as such, though the color photographs are numerous and lovely, and its excellent bibliography points the reader toward a fair number of the best books about those crafts. Instead, it is a wonderfully nuanced case study of the creation of the image of a nation following the nineteenth-century European model of focusing on romanticized peasants and, more generally, of the politics surrounding crafts and their exhibition. 